\title{
Size distribution and diffuse pollution impacts of PAHs in street dust in urban streams in the Yangtze River Delta
}

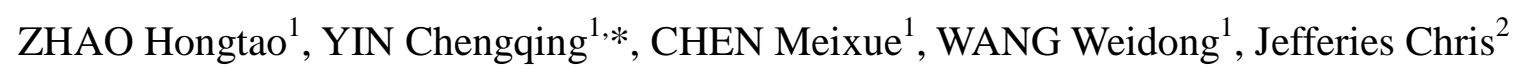

1. State Key laboratory of Environmental Aquatic Chemistry, Research Center for Eco-Environmental Sciences, Chinese Academy of Sciences, Beijing 10085, China. E-mail: htzhao@163.com

2. Urban Water Technology Centre, University of Abertay Dundee, Bell Street, Dundee, Scotland DD1 1HG, UK

Received 25 March 2008; revised 30 April 2008; accepted 28 May 2008

\begin{abstract}
Particles of dust washed off streets by stormwater are an important pathway of polyaromatic hydrocarbons (PAHs) into urban streams. This paper presents a comprehensive assessment of the size distribution of PAHs in street dust particles, the potential risks of the particles in urban streams, and the sources and sinks of PAHs in the stream network. This assessment is based on measurements of 16 PAHs from the US EPA priority list in street dust particles and river sediments in the small town of Xincheng in China. The concentration of total PAHs ranged from 1,629 to $8,986 \mu \mathrm{g} / \mathrm{kg}$ in the street dust particles, fractions with smaller particle diameters having higher concentrations. Approximately 55\% of the total PAHs were associated with particles less than $250 \mu \mathrm{m}$ in diameter which accounted for $40 \%$ of the total mass of street dust. The PAH quantities ranged from 2.41 to $46.86 \mu \mathrm{g} / \mathrm{m}^{2}$ with concentration ranging from the lowest in new residential, rising through main roads, old town residential and commercial to the highest concentrations in industrial areas. The sediments in the stream reaches in the town were found to be sinks for street dust particle PAHs. The research findings suggest that particle size, land use and the hydrological conditions in the stream network were the factors which most influenced the total loads of PAH in the receiving water bodies.
\end{abstract}

Key words: PAHs; Street dust particle; size distribution; land use; pollutant load

\footnotetext{
* Corresponding author. E-mail: cqyin@263.net
}

\section{Introduction}

Polycyclic aromatic hydrocarbons (PAHs) are a group of ubiquitous environmental 
pollutants, some of which are known to be mutagenic or carcinogenic (Ravindra et al., 2008). PAHs are released to the environment through anthropogenic activities such as production and combustion of fossil fuels, and biomass (Omar et al., 2002), and they enter surface waters through different pathways including atmospheric fallout, urban runoff and municipal/industrial effluents (Zhu et al., 2004). Input of PAHs from point sources has gradually decreased because of enhanced discharge control (Schneider et al., 2001), while input of PAHs from urban stormwater runoff has increasingly been reported as one of the most frequent causes of surface water pollution (Brenner et al., 2002). PAHs in stormwater runoff tend to partition onto solid particles (Li et al., 2006), and street dust particles in urban runoff act as a transport medium for PAHs (Brown and Peake, 2006; Herngren, et al., 2006). PAHs in street dust have various origins: weathering of materials from street surfaces, automobile exhausts, tyre particles, and atmospherically deposited materials (Takada et al., 1990). Street surfaces are at the same time, sources of urban runoff pollutants and pathways for the transport of pollutants (Sartor and Gaboury, 1984). Street sweepers play an important role in removing litter and debris, but they are relatively ineffective in removing small particles (Chang et al., 2005).

Spatial influences such as location, distribution and proportions of watershed areas can crucially affect the export of pollutants (Yin et al., 1993; Wang et al., 2005). Stream networks are extensive in big river deltas (Saco and Kumar, 2002; Thomas et al., 2004) and there are many locations where polluted runoff can enter the watercourses without buffer strips for pollutant control (Wang et al., 2005). The population density is usually high, and in China these regions are urbanizing rapidly with significant increases in impermeable areas. Abundant rainfall, and a crisscrossing network of canals accelerates the transport of street dust particles into water bodies by surface runoff. In addition, the velocity of water in stream networks is slow resulting in sediment accumulation (Salant et al., 2008). Unfortunately, some potential drinking water sources in this area have become contaminated with micropollutants such as PAHs by stormwater runoff (Chen et al., 2007). Thus, the stream network of the Yangtze delta, which is one of the most developed areas in East China, suffers from severe contamination of PAHs arising from non-point urban sources.

The size of street dust particles, the land use, landscape spatial patterns and hydrological 
conditions in urban stream networks are important factors in the control of PAH wash-off into the aquatic environment. However, previous studies of the particle size distribution of street dust did not involve patterns of land use, nor the wash off of street dust to the stream network. Little information is available in the literature on the PAH distribution in the different size-fractions of street dust particles in stream networks and their environmental impacts, although urban runoff has been recognized as an important PAH pathway in sedimentation (Krein and Schorer, 2000; Brenner et al., 2002; Murakami et al., 2005).

The objectives of this study were to determine: (i) the important fractions of particle-bound PAH and; (ii) the impact of street dust particles on the receiving stream network.

\section{Materials and methods}

\subsection{Description of the study}

Xincheng, a town in the province of Zhejiang and typical of towns in the Yangtze River Delta, China was selected as the study site. The town has a population of about 18,000 and an urban area of around $6.2 \mathrm{~km}^{2}$. It has a warm and humid climate with four distinct seasons and abundant rainfall. The annual mean temperature is $15.9{ }^{\circ} \mathrm{C}$, the annual average rainfall is $1,180 \mathrm{~mm}$ and the stream density is $3.5 \mathrm{~km} / \mathrm{km}^{2}$. There are few storm sewers and runoff discharges directly into the adjacent streams. Xincheng has many small factories and workshops producing wine, textiles and hardware and the traffic is heavy. It is proposed to abstract drinking water from the Xincheng River which passes through the town with a very low velocity of flow. The streets are swept daily with straw brooms, and sweeping is generally finished before 8:30 a.m.

\subsection{Sample collection and size fractioning methods}

Street dust particles were collected by a vacuum cleaner after the daily sweeping in March 2006. The street dust sampling sites were selected to represent the following typical street categories: three in main traffic arteries (R1, R2, R3), three industrial (I1, I2, I3), three commercial (C1, C2, C3), two older residential areas (OR1, OR2), and four in new residential streets (NR1, NR2, NR3, NR4). The masses of street dust per unit area of street surface are 
recorded and are shown in Table 1 . The new residential area differs from the older residential area in the frequency of sweeping and other management measures. Sites R1, R2, and R3 are paved with asphalt and the others are concrete.

Table 1 Mass of street dust per unit area of street surface by grain size fraction for roads from several urban districts

\begin{tabular}{|c|c|c|c|c|c|c|}
\hline \multirow{2}{*}{ Land use* } & \multicolumn{6}{|c|}{ Mass of street dust per area $\left(\mathrm{g} / \mathrm{m}^{2}\right)$} \\
\hline & $\sum$ diameter & $>900 \mu \mathrm{m}$ & 250--900 $\mu \mathrm{m}$ & $125--250 \mu \mathrm{m}$ & $63--125 \mu \mathrm{m}$ & $<63 \mu \mathrm{m}$ \\
\hline $\mathrm{C} 1$ & 2.5 & 0.4 & 0.9 & 0.5 & 0.4 & 0.3 \\
\hline $\mathrm{C} 2$ & 5.6 & 1.4 & 2.6 & 0.8 & 0.5 & 0.3 \\
\hline $\mathrm{C} 3$ & 17.5 & 5.2 & 7.5 & 2.5 & 1.7 & 0.6 \\
\hline I1 & 9.6 & 0.7 & 3.5 & 2.5 & 1.9 & 0.9 \\
\hline $\mathrm{I} 2$ & 24.2 & 9.5 & 10.3 & 2.6 & 1.3 & 0.5 \\
\hline I3 & 23.0 & 7.8 & 9.5 & 3.2 & 1.7 & 0.8 \\
\hline NR1 & 12.0 & 2.5 & 6.5 & 1.5 & 1.0 & 0.5 \\
\hline NR2 & 10.4 & 1.2 & 6.0 & 2.1 & 0.9 & 0.3 \\
\hline NR3 & 5.9 & 2.8 & 1.7 & 0.5 & 0.4 & 0.5 \\
\hline NR4 & 2.2 & 0.5 & 0.9 & 0.4 & 0.3 & 0.2 \\
\hline OR1 & 8.7 & 1.0 & 3.1 & 1.7 & 1.7 & 1.2 \\
\hline OR2 & 13.8 & 4.2 & 5.1 & 2.1 & 1.5 & 0.8 \\
\hline R1 & 5.1 & 1.0 & 2.5 & 1.1 & 0.5 & 0.1 \\
\hline $\mathrm{R} 2$ & 14.0 & 1.1 & 6.0 & 3.5 & 2.3 & 0.9 \\
\hline R3 & 21.1 & 8.1 & 7.5 & 3.0 & 1.8 & 0.6 \\
\hline
\end{tabular}

* C, I, NR, OR and R: commercial, industrial, new residential, old residential streets and main traffic roads.

The stream sediment samples (from the top $15 \mathrm{~cm}$ ) were collected using a stainless steel grab sampler. Six sediment sampling sites were chosen along the Xincheng River. Three river sediments were collected from upstream (sed1), in the town section (sed2), and downstream (sed3) of Xincheng (Fig. 1) and each consisted of two samples. The top $10 \mathrm{~cm}$ of the town soils were sampled from four sites - roadside, kindergartens, public squares and fallow land. 


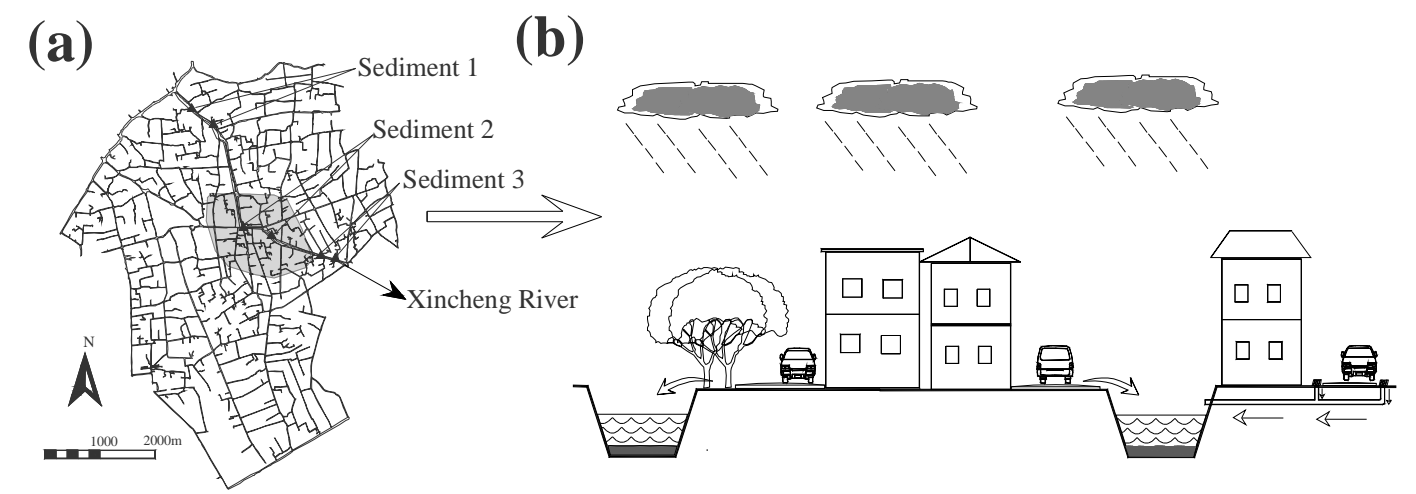

Fig. 1 (a) Study area, stream network and sampling points; (b) Schematic of runoff into the stream network

Street dust particle size fractioning used a set of stainless steel sieves. Particles were fractioned into five sizes with diameters of < 63, 63--125, 125--250, 250--900 and > $900 \mu \mathrm{m}$. PAHs were analyzed for particle size fractions smaller than $900 \mu \mathrm{m}$ from each land use sample. The larger fractions (>900 $\mu \mathrm{m}$ ) were not analyzed because they are more efficiently removed by existing street sweepers (Lau and Stenstrom, 2005). All samples were freeze-dried before the PAHs were extracted.

\subsection{Analytical methods}

The standards used were 16 USEPA priority PAHs [naphthalene (Nap), acenaphthylene (Acy), acenaphthene (Ace), fluorine (Fl), phenanthrene (Phe), anthracene (An), fluoranthene (Flu), pyrene (Pyr), benzo[a]anthracene $(\mathrm{BaA})$, chrysene $(\mathrm{Chr})$, benzo[b]fluoranthene $(\mathrm{BbF})$, benzo[k]fluoranthene $(\mathrm{BkF})$, benzo[a]pyrene $(\mathrm{BaP})$, indeno[1,2,3-cd]pyrene (Inp), dibenzo[a,h]anthracene (DBA), and benzo[ghi]perylene (BgP) ] in a solution of $2000 \mu \mathrm{g} / \mathrm{mL}$ and surrogate standards (acenaphthene-d10, phenanthrene-d10, chrysene-d12, perylene-d12) in a mixture solution of $500 \mu \mathrm{g} / \mathrm{mL}$. Both were purchased from Supelco Co. Cat., (USA). All organic solvents of pesticide analytical grade were obtained from Fisher Co., (USA).

Street dust particles, sediment and soil samples were extracted with a Soxhlet apparatus. Each sample $(10 \mathrm{~g})$ was spiked with four surrogate standards (acenaphthene-d10, phenanthrene-d10, chrysene-d12, perylene-d12), and then extracted with $200 \mathrm{~mL}$ of 
methylene chloride for $48 \mathrm{~h}$, to which activated copper was added for desulphurization. The extract was pre-concentrated to $2 \mathrm{~mL}$ by a rotary evaporator and the solvent was exchanged with hexane. The hexane extract was fractioned and cleaned up using an LC-Si SPE Tube (No. SP7953C, Supelco Co. Cat., USA) capped with anhydrous sodium sulfate $(1 \mathrm{~cm})$. The tubes were eluted with $70 \mathrm{~mL}$ of methylene chloride/hexane $(V / V, 3: 7)$ to obtain PAHs. The PAH fraction was finally concentrated to $1 \mathrm{~mL}$ under a gentle stream of nitrogen.

The concentrations of PAHs in the extracts were determined using an Agilent 6890N gas chromatograph (GC) (USA) equipped with a splitless injector, HP-5 capillary column (30 $\mathrm{m} \times$ $0.25 \mathrm{~mm}$ inner diameter $\times 0.25 \mu \mathrm{m}$ film thickness) and a 5973 mass selective detector (MSD) (Agilent, USA). The carrier gas was helium (ultra high purity) at a constant flow rate of 1 $\mathrm{mL} / \mathrm{min}$. The GC oven temperature was programmed from $50(2 \mathrm{~min})$ to $200^{\circ} \mathrm{C}(2 \mathrm{~min})$ at 20 ${ }^{\circ} \mathrm{C} / \mathrm{min}$, then to $240^{\circ} \mathrm{C}(2 \mathrm{~min})$ at $5^{\circ} \mathrm{C} / \mathrm{min}$ before reaching $290^{\circ} \mathrm{C}$ at $3^{\circ} \mathrm{C} / \mathrm{min}$ and held for 15 min. The injector and detector temperatures were 280 and $300{ }^{\circ} \mathrm{C}$, respectively. Chromatographic data were collected and processed using HP Chemstation software. Detection limits were 1.1--5.3 $\mu \mathrm{g} / \mathrm{kg}$ dry weight for PAHs. All the results were expressed on a dry weight basis.

Total organic matter $(\mathrm{OM})$ was determined by ignition at $550^{\circ} \mathrm{C}$ for $2 \mathrm{~h}$ (Vollenweider, 1969). The density of the street dust particles was measured with a pycnometer (Blake and Harge, 1986).

\subsection{Quality assurance and quality control}

Laboratory quality control procedures included the analytical methods of blanks (solvent), spiked blanks (standards spiked into solvent), matrix spikes/matrix spike duplicates, and sample duplicates. The recoveries for four surrogate standards (acenaphthene-d10, phenanthrene-d10, chrysene-d12, perylene-d12) were $(59.5 \pm 11.2) \%,(83.7 \pm 9.3) \%,(94.1 \pm$ $6.7) \%$, and $(85.6 \pm 12.4) \%$, respectively.

\subsection{Statistical}


SPSS 11.5 was used for statistical analysis including correlation and classification. Origin Pro7.5 was chosen as the graphing software. All data in the column figures are presented with mean \pm standard deviation.

\section{Results}

\subsection{PAH contents in street dust, soil and river sediment}

The contents of total PAHs in street dust particles $(<900 \mu \mathrm{m})$ ranged from 1,629 to 8,986 $\mu \mathrm{g} / \mathrm{kg}$. The mean concentration of the sediments in the Xincheng stream network was 4,130 $\mu \mathrm{g} / \mathrm{kg}$ (Fig. 2). Of the five land use types, the dust particles collected from streets in the industrial area (I) had the highest PAH content, while that from the new residential areas (NR) had the lowest. The PAH concentrations in the sediments from the different reaches of Xincheng River varied greatly. Much higher total PAH concentrations were found in the town reach sediment (sed2) where the values were comparable to street dust. Much lower PAH concentrations were found in the upstream and downstream reaches and the town soil.

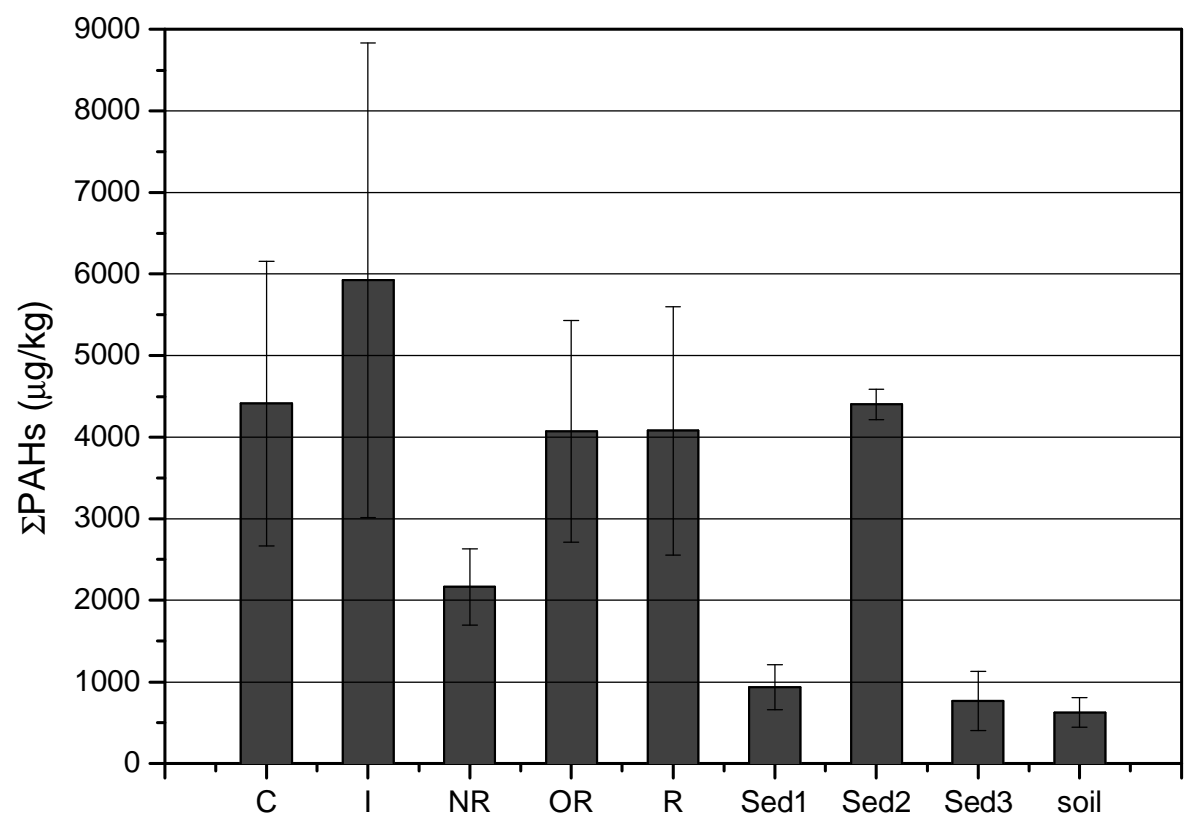


Fig. 2 Total polycyclic aromatic hydrocarbons (PAHs) content of street dust from several urban districts.

\subsection{Size distribution of total PAH in street dust particles}

The total PAH and organic content in the street dust particles with different size fractions showed a grain size gradient. The organic content varied from $2.1 \%$ to $21.2 \%$ in the four size fractions. Higher concentrations of PAHs and organic matter were found in street dust particles with smaller grain sizes (Fig. 3). The Pearson correlation coefficients for the relationship between organic matter and PAHs in < 63, 63--125, and 125--250 $\mu \mathrm{m}$ fractions were $0.839,0.714,0.645$ at the 0.01 level (2-tailed), respectively, and that in 250--900 $\mu \mathrm{m}$ was 0.578 at 0.05 level (2-tailed). The smaller street dust particles had the stronger correlations.

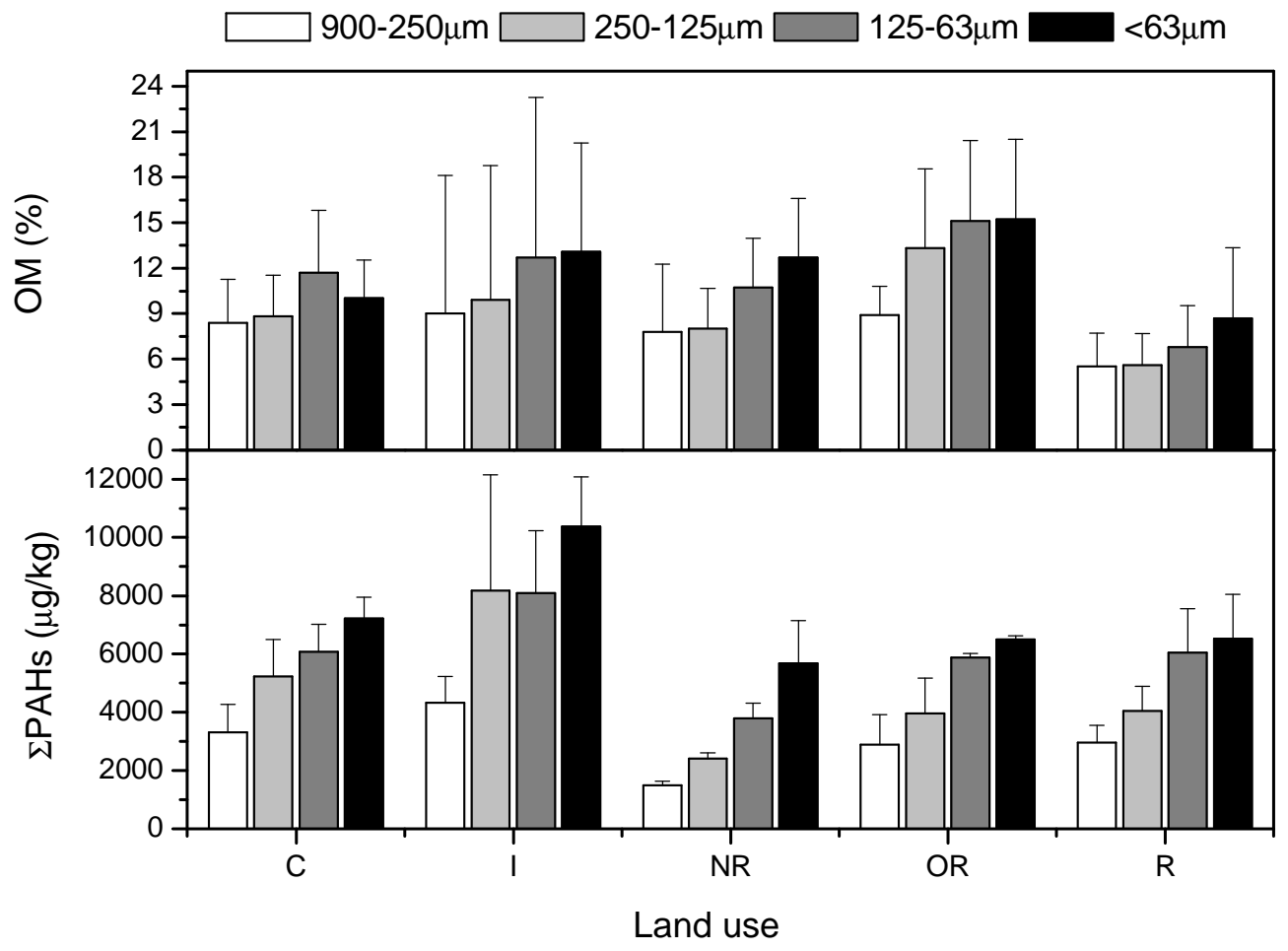

Fig. 3 Organic matter content and total PAHs content in the size-fractions of the street dust particles. 


\subsection{Potential risks of street dust particles to the stream network}

Surface runoff caused by rainfall is a primary transport pathway for PAHs to receiving water bodies, the distance between the pollution source and receiving water being one of the key factors which controls the amount transported (Lu et al., 2007). In this study, the greatest distances between the street and the receiving water were generally not more than $150 \mathrm{~m}$. The street dust particles enter the receiving waters by either direct surface flow or conduit flow (Fig. 1). In most locations there were no buffer strips between the street and the receiving water and in general, the transport pathways of PAHs were short and the flush rapid.

The mobility of pollutants and their concentration in the source area was also an important factor in determining the pollutant load. The smaller street dust particles had lower densities, indicating that smaller particles have high mobility in runoff (Fig. 4).

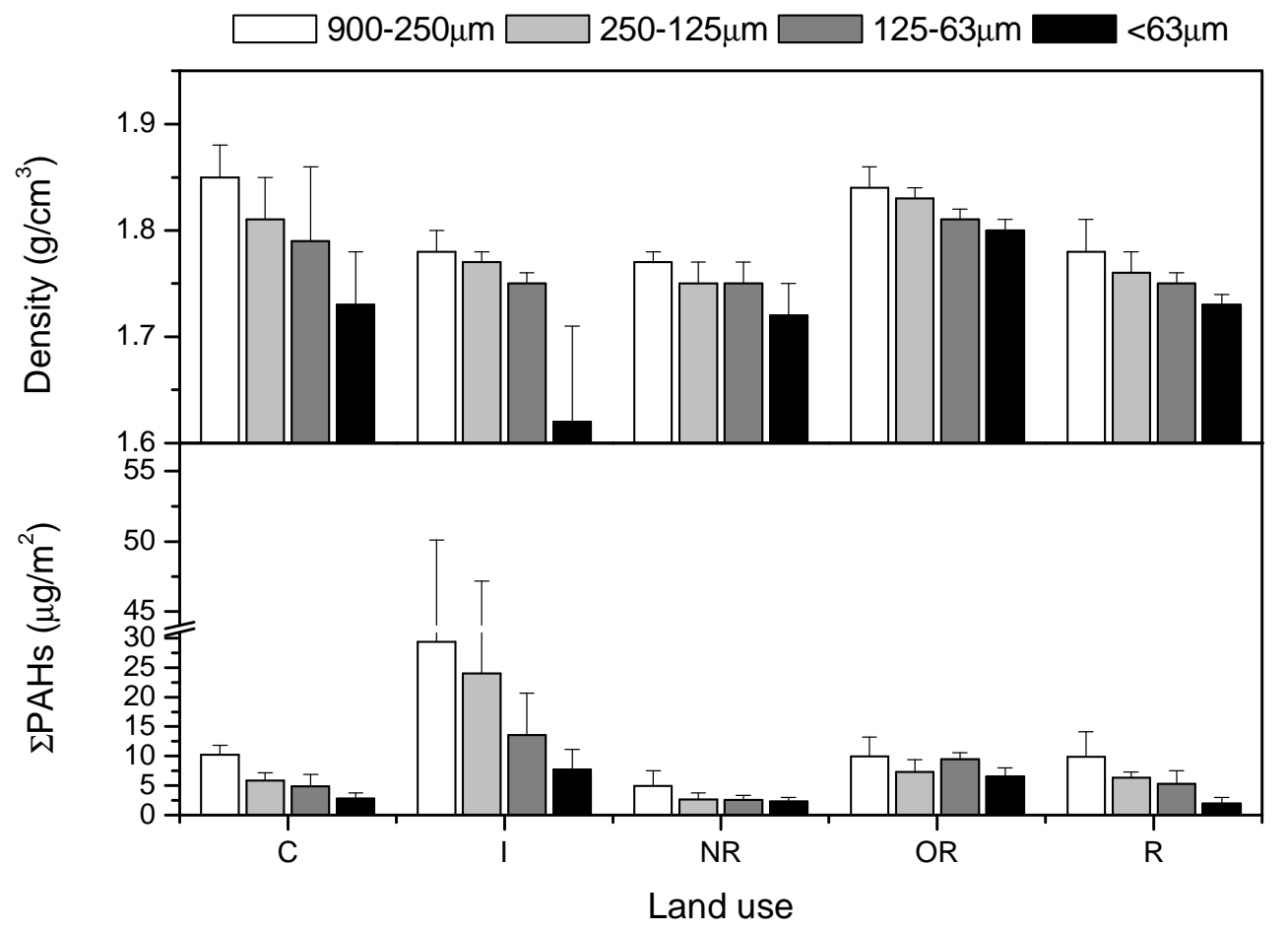

Fig. 4 Density of street dust particles and total PAH amount per unit area of paved surface.

The total PAHs per unit area of street dust ranged from 12.40 to $74.79 \mu \mathrm{g} / \mathrm{m}^{2}$, with a 
mean of $33.56 \mu \mathrm{g} / \mathrm{m}^{2}$. Of the five land use types, street dust particles collected from industrial areas (I) had the highest PAH concentrations, while the new residential (NR) areas had the least total PAH per unit area (Fig. 4). Approximately 55\% of total PAH were present in particles with diameters of less than $250 \mu \mathrm{m}$, accounting for $40 \%$ of the street dust particle weight (Fig. 5).

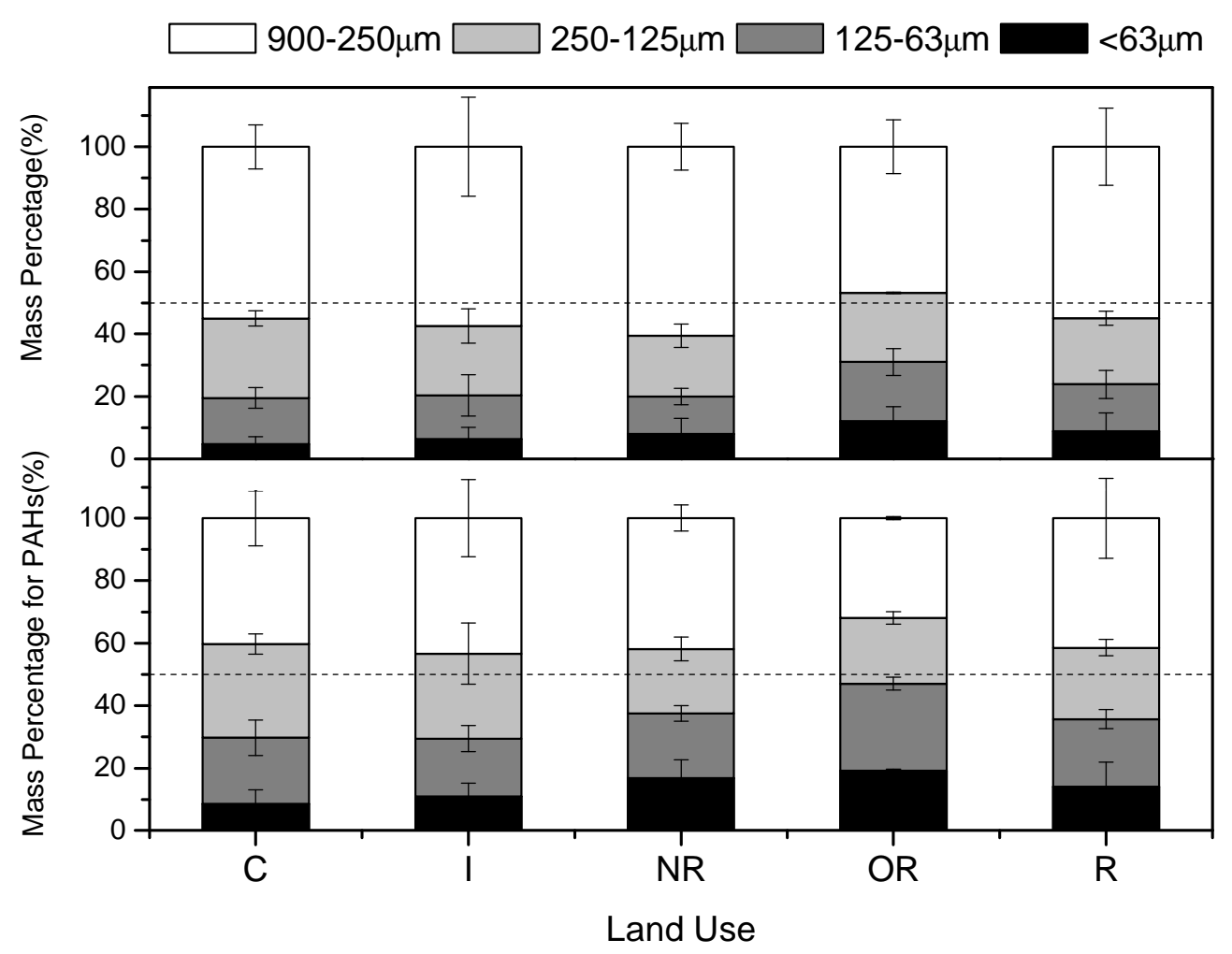

Fig. 5 Mass percentage of street dust and PAHs in different particle sizes.

\subsection{Impact of street dust particle on receiving water}

Street dust particles were found to accumulate in the sediments close to the point of entry into the network and it is inferred that this is due to low stream velocities. The evidence for this is given in fig. 2 which shows that the town reach sediment (sed2) had much higher total PAHs content than the sediments in the upstream and downstream reaches.

The effects range low (ERL) and the effects range median (ERM) values were used for 
assessment of the aquatic sediment with a ranking of low to high impact values (Long et al., 1995). ERL and ERM represent the concentrations below and above which toxic effects are probable respectively. The range between ERL and ERM represents concentrations where toxic effects are possible. Several PAH components in the town reach sediments were in the range between ERL and ERM (Table 3), indicating their potential toxic impact. Several PAH components in the town reach sediments were in the range between ERL and ERM (Table 2), indicating their potential toxic impact. The street dust particles with diameters lees than 63 $\mu \mathrm{m}$ had even higher PAH content and it is expected that if the runoff continues washing the street dust particles into the river, the sediment PAH content would probably continue to increase.

Table 2 Pollution criteria of PAH components for sediment matrix $(\mu \mathrm{g} / \mathrm{kg})$

\begin{tabular}{lllllll}
\hline Compound & ERL & ERM & sed1 & sed2 & sed3 & $<63 \mu \mathrm{m}$ \\
\hline Nap & 160 & 2100 & 28 & 147 & 19 & $322^{\mathrm{a}}$ \\
Acy & 44 & 640 & 7 & 9 & 2 & $86^{\mathrm{a}}$ \\
Ace & 16 & 500 & 2 & $36^{\mathrm{a}}$ & 3 & $33^{\mathrm{a}}$ \\
Fl & 19 & 540 & 12 & 83 & 8 & 158 \\
Phe & 240 & 1500 & 74 & $576^{\mathrm{a}}$ & 28 & $1022^{\mathrm{a}}$ \\
An & 853 & 1100 & 16 & 78 & 6 & 168 \\
Flu & 600 & 5100 & 126 & 525 & 81 & $925^{\mathrm{a}}$ \\
Pyr & 665 & 2600 & 102 & 454 & 109 & 645 \\
BaA & 261 & 1600 & 92 & $318^{\mathrm{a}}$ & 62 & $364^{\mathrm{a}}$ \\
CHr & 384 & 2800 & 125 & 457 & 122 & $613^{\mathrm{a}}$ \\
BbF & NA & NA & 153 & 585 & 156 & 917 \\
BkF & NA & NA & 53 & 234 & 38 & 315 \\
BaP & 430 & 1600 & 113 & 358 & 95 & $537^{\mathrm{a}}$ \\
InP & NA & NA & 1 & 76 & 7 & 229 \\
DBA & 63 & 260 & 1 & $222^{\mathrm{a}}$ & 2 & $436^{\mathrm{b}}$ \\
BgP & NA & NA & 30 & 245 & 30 & 491 \\
Total & 4000 & 44792 & 934 & 4402 & 767 & 7261 \\
\hline & & 152 & & & \\
\hline
\end{tabular}

ERL: effects range low; ERM: effects range median; 
${ }^{\text {a }} \mathrm{PAH}$ are in the range between ERL and ERM;

${ }^{\mathrm{b}} \mathrm{PAH}$ are in the range above ERM;

NA: not available.

The PAH profiles in the street dust particles and the town reach sediments $(\operatorname{sed} 2)$ were similar. Most samples of the dust particles, soils and sediments satisfied the criteria of Phe/An $<10$ and Flu/Pyr $>1$. The Phe/An ratio and Flu/Pyr ratio is used to distinguish petrogenic and pyrogenic sources of PAHs (Shi et al., 2007). This indicates that combustion was the dominant source of the PAHs. To statistically examine the similarity of the PAH profiles among the town reach sediments and potential source materials, a hierarchical cluster analysis (HCA) was conducted. Fig. 6 shows the results in a HCA dendrogram. The samples were classified into two cluster groups G1 and G2, indicating that the sediments from upstream and downstream were quite different from the other samples. A high degree of similarity in the PAH profiles was found between the town reach sediments (sed2) and $<63 \mu \mathrm{m}$ fractions of the street dust. This result provides further evidence that the street dust particles were the major source of PAHs in the stream sediments.

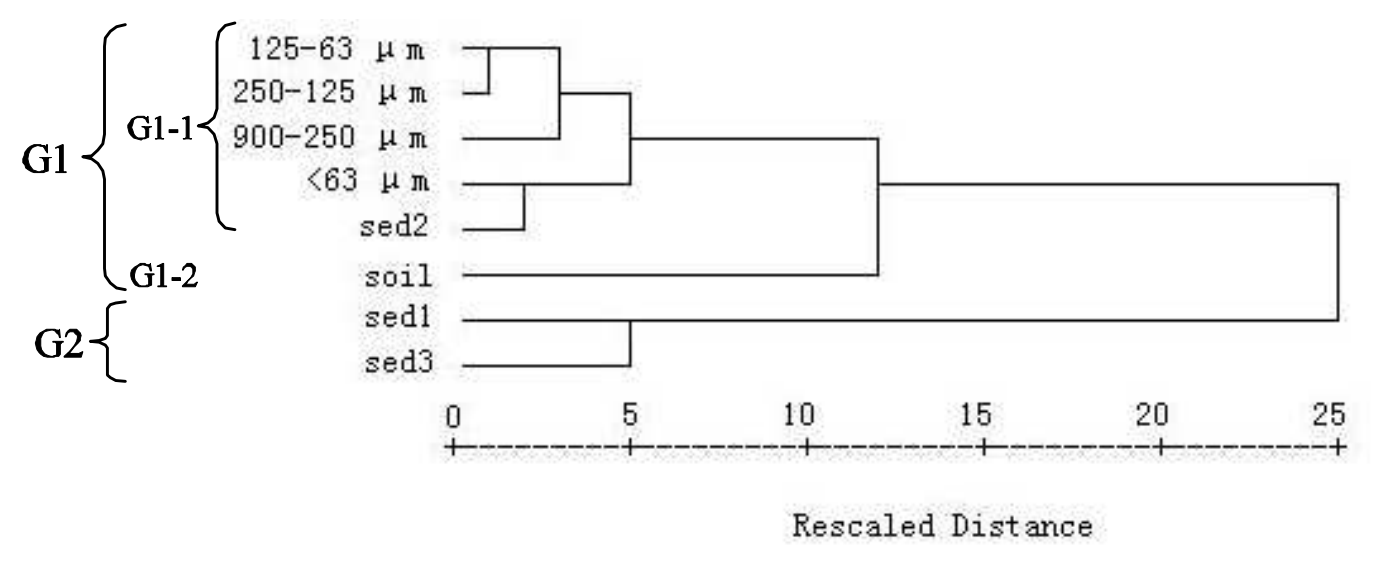

Fig. 6 Dendrogram of PAH profiles in street dust, sediment, and town soil samples by Ward's method. The profiles of town reach sediment (sed2) and street dust particle $(<63 \mu \mathrm{m})$ show a high degree of similarity. 


\section{Discussion}

\subsection{Potential risks of street dust particles to receiving water}

Street dust is the major source of PAH pollution into the stream network of Xincheng, this being a similar finding to that of Motelay-Massei et al., (2006). Hoffman et al. (1984) estimated that $36 \%$ of aquatic environmental PAH input was due to urban runoff, and was the greatest single source. The size of the street dust particles is critical in influencing the potential risk of contamination to the receiving water (Krein and Schorer, 2000). Smaller street dust particles have higher PAH and organic contents due to their greater specific surface area which favors the adsorption of pollutants (Roger et al., 1998). The smaller particles have greater PAH concentrations in the street area since they have less density, higher mobility and less settleability (Aryal et al., 2005; Murakami et al., 2005). This infers that the smaller particles are more likely to be washed by urban runoff and pose a greater risk to the receiving water body.

\subsection{Hydrological and land use characteristics of the stream network under the impact of} street dust pollution

The stream network studied is located in the Yangtze River Delta where the flat topography and many flow routes reduce the peak runoff velocity in the stream network (Troch et al., 1995; Saco and Kumar, 2002). The outfall is frequently covered at high water levels which may be caused by high tides or control gates causing sediments to accumulate at particular sites due to low velocities (Salant et al., 2008). The thickness of the sediments of this area range from 0.5 to $0.9 \mathrm{~m}$ and the mean sediment deposition rate in the streams is 0.11--0.32 m/year (Zhou and Zheng, 2002). Distances between the streets and the receiving waters are short and there are no buffer strips. This result in significant in the receiving water bodies (Heathwaite et al., 2005; Lu et al., 2007).

The pattern of land use may have important pollution impact. In this research, it was found that the streets in the industrial area had a greater dust deposition rate and street dust had a higher PAH content. The streets in the industrial area have rough surfaces, resulting in a permanent source of street dust (Pitt et al., 2004) although the dust particles can be cleaned by street flushing (Chang et al., 2005). In contrast, the town streets are hand swept with brooms, a method which is relatively ineffective for removing small particles (Bender and Terstriep, 
1984) which have a high PAH resulting in small particles being more easily washed to the stream network.

It is proposed that buffer strips or other control measures should be constructed to reduce the wash off of street dust into the stream network following the principles of Best Management Practices. The existing street cleaning methods should also be improved to reduce the number of dust particles on street surfaces.

\section{Conclusions}

PAHs associated with street dust particles washed into the stream network are an important source of PAHs in aquatic sediments in the urban area. Approximately $55 \%$ of the total PAHs were associated with particles of diameters less than $250 \mu \mathrm{m}$ and these accounted for $40 \%$ of the total mass of street dusts. Smaller street dust particle had higher contents of total PAHs, and organic matter, and lower densities, causing them to be of higher risk due to their mobility and PAHs contamination during urban runoff.

Acknowledgments: This work was supported by the Key Project of Zhejiang Province (No. 2006C13057), CAS Program (No. KZCX1-YW-06-02) and Jiaxing City Project (No. 2005AZ3040). The authors were grateful to Jiaxing Academy of Agriculture Sciences and the Bureau of Water Resources of Jiaxing City for their field assistance.

\section{References}

Aryal R K, Furumai H, Nakajima F, Boller M, 2005. Dynamic behavior of fractional suspended solids and particle-bound polycyclic aromatic hydrocarbons in highway runoff. Water Research, 39: 5126--5134.

Bender G M, Terstriep M L, 1984. Effectiveness of street sweeping in urban runoff pollution control. Science of the Total Environment, 33: 185--192.

Blake G R, Hartge K H, 1986. Particle density. In: Methods of Soil Analysis. Part 1. Physical and Mineralogical Methods (Klute A., ed.). Madison: American Society of Agronomy. $377--382$.

Brenner R C, Magar V S, Ickes J A, Abbott J E, Stout S A, Crecelius E A, Bingler L S, 2002. Characterization and fate of PAH-contaminated sediments at the Wyckoff/Eagle Harbor 
Superfund site. Environmental Science and Technology, 36: 2605--2613.

Brown J N, Peake B M, 2006. Sources of heavy metals and polycyclic aromatic hydrocarbons in urban stormwater runoff. Science of the Total Environment, 359: 145--155.

Chen L G, Ran Y, Xing B S, Mai B X, He J h, Xu W G, Fu J M, Sheng G Y, 2005. Contents and sources of polycyclic aromatic hydrocarbons and organochlorine pesticides in vegetable soils of Guangzhou, China. Chemosphere, 60: 879--890.

Chen Y Y, Zhu L Z, Zhou R B, 2007. Characterization and distribution of polycyclic aromatic hydrocarbon in surface water and sediment from Qiantang River, China. Journal of Hazardous materials, 141: 148--155.

Heathwaite A L, Quinn P F, Hewett C J W, 2005. Modeling and managing critical source areas of diffuse pollution from agricultural land using flow connectivity simulation. Journal of Hydrology, 304: 446--461.

Herngren L, Goonetilleke A, Ayoko G A, 2006. Analysis of heavy metals in road-deposited sediments. Analytica Chimica Acta, 571: 270--278.

Hoffman E J, Mills G L, Latimer J S, Quinn J G, 1984. Urban runoff as a source of polycyclic aromatic hydrocarbons to coastal waters. Environmental Science and Technology, 18: $580--587$.

Krein A, Schorer M, 2000. Road runoff pollution by polycyclic aromatic hydrocarbons and its contribution to river sediments. Water Research, 34: 4110--4115.

Lau S L, Stenstrom M K, 2005. Metals and PAHs absorbed to street particles. Water Research, 39: 4083--4092.

Li Y, Lau S L, Kayhanian M, Asce M, Stenstrom M K, Asce F, 2006. Dynamic characteristics of particle size distribution in highway runoff: Implications for settling tank design. Journal of Environment Management, 132: 852--861.

Long E R, MacDonald D D, Smith S L, Calder F D, 1995. Incidence of adverse biological effects within ranges of chemical concentrations in marine and estuary sediments. Environment Management, 19: 81--97.

Lu H M, Yin C Q, Wang W D, Shan B Q, 2007. A comparative study of nutrient transfer via surface runoff from two small agricultural catchments in north China. Environmental Geoogyl, 52: 1549--1558. 
Motelay-Massei A, Garban B, Tiphagne-larcher K, Chevreuil M, Ollivon D, 2006. Mass balance for polycyclic aromatic hydrocarbons in the urban watershed of Le Havre (France): transport and fate of PAHs from the atmosphere to the outlet. Water Research, 40: 1995--2006.

Murakami M, Nakajima F, Furumai H, 2005. Size- and density-distributions and sources of polycyclic aromatic hydrocarbons in urban road dust. Chemosphere, 61: 783--791.

Omar N Y M J, Bin Abas M R, Ketuly K A, Tahir N M, 2002. Concentrations of PAHs in atmospheric particles (PM-10) and roadside soil particles collected in Kuala Lumpur, Malaysia. Atmospheric Environment, 36: 247--254.

Pitt R, Williamson D, Voorhees J, Clark S, 2004. Review of historical street dust and dirt accumulation and washoff data. In: Effective Modeling of Urban Water Systems, Monograph 13. (James W., Irvine K. N., McBean E. A., Pitt R. E., eds.). Ontario: Computational Hydraulics International. 43--54.

Ravindra K, Sokhi R, Van Grieken R, 2008. Atmospheric polycyclic aromatic hydrocarbons: Source attribution, emission factors and regulation. Atmospheric Environment, 42: 2895--2921.

Roger S, Montrejaud-Vignoles M, Andral M C, 1998. Mineral, physical and chemical analysis of the solid matter carried by motorway runoff water. Water Research, 32: 1119--1125.

Saco P M, Kumar P, 2002. Kinematic dispersion in stream networks: 1. Coupling hydraulic and network geometry. Water Resources Research, 38(11): 1244--1255.

Salant N L, Hassan M A, Alonso C V, 2008. Suspended sediment dynamics at high and low storm flows in two small watersheds. Hydrological Processes, 22: 1573--1587.

Sartor J A, Gaboury D R, 1984. Street sweeping as a water pollution control measure: lessons learned over the past ten years. Science of the Total Environment, 33: 171--183.

Schneider A R, Stapleton H M, Cornwell J, Bake J E, 2001. Recent declines in PAH, PCB, and toxaphene levels in the northern Great Lakes as determined from high resolution sediment cores. Environmental Science and Technology, 35: 3809--3815.

Shi Z, Tao S, Pan B, Liu W X, Shen W R, 2007. Partitioning and source diagnostics of polycyclic aromatic hydrocarbons in rivers in Tianjin, China. Environmental Pollution, 
146: 492--500.

Takada H, Onda T, Ogura N, 1990. Determination of polycyclic aromatic hydrocarbons in urban street dust and their source materials by capillary gas chromatography. Environmental Science and Technology, 24: 1179--1186.

Thomas S M, Neill C, Deegan L A, Krusche A V, Ballester V M, Victoria R L, 2004. Influences of land use and stream size on particulate and dissolved materials in a small Amazonian stream network. Biogeochemistry, 68; 135--151.

Troch P A, De Troch F P, Mancini M, Wood E F, 1995. Stream network morphology and storm response in humid catchments. Hydrological Processes, 9: 575--587.

Vollenweider R A, 1969. A Manual on Methods for Measuring Primary Production in Aquatic Environments. Oxford: Blackwell Scientific Publishers.

Wang X H, Yin C Q, Shan B Q, 2005. The role of diversified landscape buffer structures for water quality improvement in an agricultural watershed, North China. Agriculture, Ecosystems and Environmen, 107: 381--396.

Yin C Q, Zhao M, Jin W G, Lan Z W, 1993. A multi-pond system as a protective zone for the management of lakes in China. Hydrobiologia, 251: 321--329.

Zhou C D, Zheng F J, 2002. Thinking on water control in recent years for Jiaxing city. Zhejiang Hydrotechnics, 6: 32--34.

Zhu L Z, Chen B L, Wang J, Shen L X, 2004. Pollution survey of polycyclic aromatic hydrocarbons in surface water of Hangzhou, China. Chemosphere, 56: 1085--1095. 